\title{
EVALUATION OF THE HEAVY METALS CONTAMINATION OF THE WATER OF THE MOULOUYA MEDIUM
}

\author{
H. Ech-chafay ${ }^{1 *}$, M.Najy $^{1}$, A. El Ghazouany ${ }^{1}$, O. Akkaoui ${ }^{1}$, M. Lachhab ${ }^{1}$, D. Belghyti ${ }^{1}$ \\ ${ }^{1}$ Laboratory of Agro-physiology, Biotechnology, Environment and Quality, Department of Biology University Ibn Tofail, \\ Faculty of Science Kenitra, Morocco - (hassanfes98@gmail.com, hamman.mohamed9@gmail.com, \\ abdellatif.elghazouany@gmail.com, omar.akkaoui1@gmail.com, Salah-825@hotmail.com, belghyti@hotmail.com)
}

KEY WORDS: Metals contamination, Ecosystems, Moulouya, Outat El Haj, Morocco.

\begin{abstract}
:
This work is part of a program to study and monitor the impact of human activities in the cities of Missour and Outat El Haj on the quality of the surface waters of the average Moulouya (Morocco).

The aim of this study is to evaluate in time and space, the degree of metallic pollution of surface water of the average Moulouya during the period (September 2014, January, April and July 2015). The results of this study suggest that the waters of the ten stations in the study area are relatively contaminated with heavy metals. The contents of the analyzed metals are high and variable in the wastewater of the cities of Missour and Outat El Haj and in the waters of the Moulouya average.

The anthropogenic impact on the ecosystems selected for this work is highlighted by: the high metallic contamination of the water of the stations located downstream of wastewater discharges of the cities of Missour and Outat El Haj, and the variation of the contents according to an increasing concentration gradient from station M1 to M9.
\end{abstract}

\section{INTRODUCTION}

Metal contamination of aquatic environments has become of global concern due to its toxicity, bioaccumulation and effects on aquatic life. Metal residues risk damaging aquatic life by accumulating in microorganisms, aquatic flora and fauna, as well as, through the uses of water (food, swimming, etc.), human health (Cook et al., 1990; Deniseger et al., 1990). Heavy metals from natural or anthropogenic sources released into an aquatic environment are largely trapped in sediments (Sin et al., 2001). Consequently, sediments are often used to assess the degree of pollution of aquatic environments (Buggy and Tobin, 2008).

In Morocco, metallic contamination of aquatic ecosystems has attracted the attention of researchers from very different backgrounds. It is indeed one of the most threatening aspects of pollution for these environments. Through its harmful effects, it could generate critical or even dangerous situations, sometimes affecting the ecological balance of these ecosystems. Indeed, this pollution is a topical problem that concerns all regions concerned with maintaining their water resources at a high level of quality (Makhoukh et al., 2011).

Several studies have investigated the extent and degree of such contaminations (Davies and Ballinger, 1990; Jung, 2001). It is in this context that we undertook the study of the impact of anthropogenic activities and residues from the mining districts of the middle Moulouya on the water components of the Moulouya wadi.

This wadi which drains almost all of eastern Morocco and the districts (Aouli - Mibladen - Zaida) in its upstream part is $\mathbf{5 2 0}$ $\mathrm{km}$ long and presents the largest Moroccan river flowing into the Mediterranean with a watershed of 'an area of approximately $50,000 \mathrm{~km} 2$.

Unlike organic pollutants liable to degrade, metallic pollutants in the aquatic environment persist. This is why the study of their mobility and transfer is of prime importance. Usually, the metals transferred to it are present in the form dissolved in water and pore water in the sediment column and attached to particles in the sediment or suspended in water. In the latter form, metals can accumulate in the sediment compartment, thus forming stocks of pollutants, potentially toxic to the environment (Devallois, 2009).

The purpose of this work is to assess the impact and the degree of contamination of anthropogenic activities in the Moulouya middle and to understand the downstream transfer of metals in the wadi. For this, water samples were taken from the Moulouya wadi and from the wastewater discharges from the towns of Missour and Outat El Haj. These samples were analyzed for major elements ( $\mathrm{Ca}$ and $\mathrm{Mg}$ ) and trace elements ( $\mathrm{Fe}, \mathrm{Zn}, \mathrm{Pb}, \mathrm{Ni}$, $\mathrm{Cu}$ and $\mathrm{Cd}$ ) were carried out on the surface waters of ten points seven positioned on the course of the Moulouya wadi and three on the wastewater collectors.

\section{MATERIALS AND METHOD}

\subsection{Presentation of the study area}

The Moulouya watershed is subdivided into three sub-basins: the upper, the middle and the lower Moulouya (Figure 1). This watercourse receives three major tributaries: Anzeghmir in Upper Moulouya then successively, Melloulou and Za in Lower Moulouya. These tributaries strongly influence the flow fluctuations of the Moulouya, with their very irregular hydrological regimes which are characterized by severe summer low water and violent floods in other seasons. Also three dam reservoirs are located on this wadi: Hassan II in the upper Moulouya, Mohamed V and Mechra-Homadi in the lower Moulouya.

Geographically, the upper Moulouya basin constitutes the western end of the Oran meseta, made up of two primary massifs, the establishment of which has caused the formation of a poly-metallic mineralization of major importance.

This region constitutes the largest district of the kingdom of Morocco (Bouabdli et al., 2005), the main minerals present in 
this district are galena, blende, barite, cerusite, chalcosite, chalcopyrite, pyrite, limonite, geothite (Emberger, 1965).

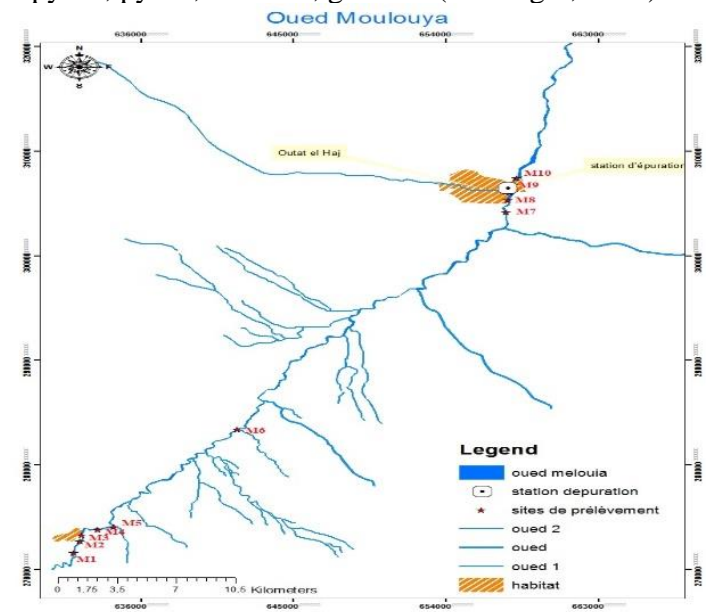

Figure 1. Localisation géographique des sites de prélèvement de l'Oued Moulouya

Along its course, this stream crosses Paleozoic-age terrain, intersected by Hercynian granite intrusions over which a Mesozoic blanket moves in unconformity (Combe and Simonot, 1971a). In the upper Moulouya, Jurassic formations (limestones, dolomitic limestones, marno-limestones), Cretaceous (marls, sandstones and limestones) as well as tertiary and quaternary formations (marl, conglomerates and gypsum (Combe and Simonot, 1971b) in the middle Moulouya.

Its rainfall regime is marked by low rainfall combined with extreme variability and irregularity. The average rainfall from 1967 to 2000 is $199.54 \mathrm{~mm}$ / year (Belghyti, 2004), sometimes more if climatic conditions favor it. Snowfall lasts for several days or even weeks on the ground and is an important source of surface runoff.

\subsection{Sample collection and preparation}

\section{Description of the sampling site:}

Taking into consideration the various activities identified in the middle Moulouya area: domestic, industrial and agricultural wastewater from the towns of Missour and Outat El Haj, water samples were taken from ten stations (M1 to M10) and which

were selected in such a way that they are accessible and reflect the real characteristics of the surface water of the Oued Moulouya, and which are distributed along the middle Moulouya (between Missour and Outat El Haj). (Figure 1).

\section{Sampling and Preparation of Water Samples}

The seasonal sampling missions were spread over the four seasons of the year from (September 2014, January, April and July 2015). For each sample, a replicate of three samples was taken in order to have the results on average for each parameter. The water samples were taken in polypropylene bottles previously washed with acid and then with distilled water, and before sampling rinsed twice with water from the site to be sampled. The water samples are acidified with $4 \%$ pure nitric acid then stored at $4{ }^{\circ} \mathrm{C}$ and transported to the laboratory within a period not exceeding 4 hours (Rodier, 2009), and once in the laboratory, a volume of $50 \mathrm{ml}$ of each sample was filtered through a millipore membrane $(0.45 \mu \mathrm{m})$, everything is kept in the refrigerator until the time of analysis.

Heavy metal assays (ETM): Flame Atomic Absorption Spectrometry

The methods for analyzing trace metals $(\mathrm{Fe}, \mathrm{Cu}, \mathrm{Zn}, \mathrm{Cd}, \mathrm{Pb}$ and $\mathrm{Ni}$ ) are those recommended by the standards

(AFNOR, 1997) and by (Rodier, 2009). The determination of trace metals was carried out on the water samples taken from each site after their filtration on a $0.45 \mu \mathrm{m}$ cellulose filter according to (Rodier, 2009), and their stabilization by $\mathrm{HNO} 3$ $50 \%(\mathrm{~V} / \mathrm{V})$ at $\mathrm{pH}=2$, according to the analysis methods recommended by the standards (AFNOR, 1997) and by (Rodier, 2009). Metallic trace elements (TME) were determined by atomic absorption spectrometry (AAS) in a GFA-EX7i graphite furnace. The device is from Perkin Elmer AA-6300 Shimadzu; Air acetylene flame, equipped with a graphite furnace GFAEX7i). It is driven by WIZAR software. The analyzes were carried out at the University Center for Analysis, Expertise, Technology Transfer and Incubator, Ibn Tofaïl University. (SAA) with GFA-EX7i graphite furnace. The device is from Perkin Elmer AA-6300 Shimadzu; Air acetylene flame, equipped with a graphite furnace GFA-EX7i). It is driven by WIZAR software. The analyzes were carried out at the University Center for Analysis, Expertise, Technology Transfer and Incubator, Ibn Tofaïl University.

\section{RESULTS AND DISCUSSIONS}

\subsection{Results}

\begin{tabular}{|c|c|c|c|c|c|c|c|c|c|c|}
\hline & M1 & M2 & M3 & M4 & M5 & M6 & M7 & M8 & M9 & M10 \\
\hline $\mathbf{C a}$ & 91,2 & 170 & 227,4 & 100,4 & 106,2 & 100,7 & 80,6 & 142,1 & 141,7 & 69,3 \\
\hline $\mathbf{M g}$ & 84,5 & 174,4 & 116,4 & 87,4 & 93 & 98,5 & 106,8 & 129,8 & 155,1 & 48,2 \\
\hline $\mathbf{N a}$ & 283,9 & 331,5 & 393,9 & 339,2 & 350,6 & 309,7 & 284,3 & 389,4 & 328,6 & 294,6 \\
\hline $\mathbf{K}$ & 11,1 & 63,9 & 52,5 & 15 & 14,8 & 12,8 & 11,2 & 71,5 & 60,7 & 13,5 \\
\hline $\mathbf{F e}$ & 2,6 & 3,8 & 6 & 4,5 & 3,1 & 4,4 & 3,3 & 5,8 & 3,6 & 3,1 \\
\hline $\mathbf{C u}$ & 0,07 & 0,11 & 0,12 & 0,12 & 0,08 & 0,17 & 0,08 & 0,13 & 0,07 & 0,05 \\
\hline $\mathbf{Z n}$ & 0,55 & 0,91 & 1,22 & 0,88 & 0,54 & 0,79 & 0,6 & 1,05 & 0,64 & 0,5 \\
\hline $\mathbf{P b}$ & 0,35 & 0,26 & 0,21 & 0,36 & 0,34 & 0,35 & 0,29 & 0,34 & 0,3 & 0,36 \\
\hline $\mathbf{C d}$ & 0,02 & 0,27 & 0,26 & 0,05 & 0,05 & 0,05 & 0,04 & 0,29 & 0,17 & 0,05 \\
\hline $\mathbf{N i}$ & 0,05 & 0,55 & 0,53 & 0,15 & 0,14 & 0,11 & 0,11 & 0,64 & 0,5 & 0,16 \\
\hline
\end{tabular}

Table 1: concentration of heavy metals in average Moulouya waters 


\subsection{Discussions}

The temperature values are then influenced by that of the air which itself depends on seasonal variations. However, the effect of this temperature on the adsorption capacity of sediments is not very significant (Serpaud et al., 1994). But, in the presence of organic matter, it can have an indirect role, for example by increasing its degradation, which can produce acidic and complexing substances (Lions, 2004) (table 1). These values measured at the level of various stations, remain below $35^{\circ} \mathrm{C}$ considered as the limit value recommended by the NMEDI (NM, 2002).

The variations in $\mathrm{pH}$ are due to the presence of carbonates which buffer the surface water flowing towards the Moulouya wadi by streaming and infiltrating in the marno - dolomitic and limestone cover, as well as in the residues of bare treatment rich in carbonate minerals deposited around it. Likewise, the Zaida ore, being essentially carbonate, essentially consists of $70 \%$ cerusite in Permo - Triassic arkoses (El Hachimi et al., 2005) (table 1).

The highest values in Calcium recorded at the stations (M2, M3, M8 and M9) are the direct result of domestic wastewater discharges from the towns of Missour and Outat El Haj and the lithological nature due to the dissociation of evaporitic rocks. mainly gypsum and anhydride which is found in this region.

The magnesium contents of the water are extremely varied and mainly related to the nature of the terrain crossed. In areas rich in magnesic rocks, water can contain concentrations of 10 to 50 $\mathrm{mg} / \mathrm{L}$ of this element, the hardness is often due to $\mathrm{Ca} 2+$ and $\mathrm{Mg} 2+$ ions.

Potassium can come from the dissolution of evaporitic minerals such as sylvite $(\mathrm{KCl})$, but also from certain minerals and fertilizers. If the potassium level is too low, different symptoms can be seen such as restricted plant growth, reduced flowering and lower yields are observed.

High water-soluble potassium levels can interfere with germination of young plants, prevent the uptake of other minerals and reduce the quality of the crop. According to WHO, the guide level for the concentration of potassium in water intended for human consumption is set at $12 \mathrm{mg} / \mathrm{l}$.

Iron concentrations generally remain low despite slightly exceeding the standards (1 mg/1), except at point M3 and M9 (16 and $14 \mathrm{ppm}$ respectively). These results allow us to conclude that this element, in addition to a natural origin, has different anthropogenic sources, which come from industrial activities present in the area, such as construction (windows, doors, gutters), and food packaging.

However, the iron values in the majority of the stations largely exceed the natural values of fresh water $(<30 \mu \mathrm{g} / 1)$ (Fahssi et al., 2016), and exceed the limit value of water intended for the production of drinking water ( $200 \mu \mathrm{g} / \mathrm{L}$ ) and the imperative value of water suitable for irrigation (5 mg / L) (NM, 2002) except for stations M2, M3, M6, M7 and M8 in January, then we can affirm that the waters of ten stations are heavily contaminated with iron during the four periods of the year.

The variation in lead levels is irregular both in time and in space.

Lead is believed to be of mainly anthropogenic origin because it is used in industry, paints and automotive fuels. The use of lead in gasoline as an anti-knock is at the origin of the increase in anthropogenic inputs of lead, of which the atmospheric route is the main source of contamination.

In addition, the lead content greatly exceeds the average content of natural uncontaminated fresh water: $0.2 \mu \mathrm{g} / 1$ (Trefry and Presley, 1976), however the waters of the Moulouya average are favorable for irrigation (content $<5 \mathrm{mg} / \mathrm{l}$ ) but exceed the production limit value for drinking water $(50 \mu \mathrm{g} / \mathrm{l})(\mathrm{NM}$, 2002).

We note, however, that the copper contents recorded in the waters of the ten stations in the four periods except M2, M3, M4, M6 and M9 (in January) do not exceed $0.2 \mathrm{ppm}$ and thus remain below the values allowed by the European community (set at $1 \mathrm{ppm}$ ).

In water, most copper comes from soil erosion by water courses (68\%), contamination by copper sulphate $(13 \%)$ and wastewater discharges which, even after treatment, still contain copper. In the Mediterranean area, the importance of runoff and erosion is likely to increase the transfer of copper-based phytosanitary products to surface water. In the case of our study area, the main natural sources of exposure would be soil dust, plant decompositions and forest fires. But the main anthropogenic sources are said to be the metal and timber industry, the incineration of household refuse, the combustion of coal, oil and gasoline, and the manufacture of fertilizers (phosphate).

The results of the cadmium analyzes showed high values

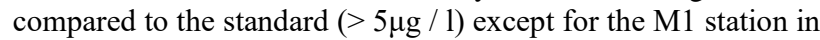
April, which proves that it has an anthropogenic origin, mainly coming from industrial effluents, deposits of water. household garbage and domestic and mixed wastewater which contains high proportions of cadmium relative to other heavy metals (WHO and UNEP, 1995).

The zinc contents recorded at the various study stations show similar seasonal fluctuations depending on the station; we note a gradual increase in zinc contents in stations M2, M3 and M9, followed by a slight decrease in stations M3 and M7. The maximum values are recorded in station M3 in January. However, it is in January and April that the zinc contents are highest (table 1). It is recalled that the stations M2, M3 and M9 are the discharges of wastewater from the towns of Missour and Outat El Haj and which directly receives the discharges of wastewater from rural agglomerations, in particular the leaching of uncontrolled household waste.

The increase in zinc concentrations in the stations (M1 to M7) during the winter period can be explained by the leaching of these waste rock by heavy rains which fall on the site. The latter can lead to runoff which transports metals to the surface water of Oued Moulouya (Makhoukh et al., 2011). The concentration of $\mathrm{Zn}$ decreases downstream and this by the phenomenon of dilution, and also by the complexations of $\mathrm{Zn}$ on the organic matter found in urban waste. This is in agreement with a similar study on the Oued de Moulouya (Lamri, 2009). The highest Zn concentrations recorded are below the direct release limit values of $5 \mathrm{mg} / 1$ (NM, 2002)

The nickel contents recorded in the surface water of the Moulouya wadis and the wastewater of the towns of Missour and Outat El Haj clearly exceed the standard accepted by the European community set at $0.05 \mathrm{ppm}$ from M2.

Natural nickel inputs are thought to be linked to soil erosion. Nickel, in urban areas, occurs in runoff; this water would 
undergo notable increases in nickel following the salting of the roads in winter. Nickel is also found in the wastewater of steel factories, paints and foundries. This would explain, in this study, the high levels observed in the stations (M2, M3, M9 and M6) in the study area.

\section{CONCLUSION}

The results of the various investigations show the impact of the urban fabric on the level of contamination of surface water by heavy metals in the Moulouya wadi. The levels of metals measured in water change differently from upstream to downstream.

Analysis of the trace elements assayed in surface water showed that the six elements sought have levels greater than the accepted standards; which characterize water polluted by these metallic elements.

These high levels are probably linked to urban discharges from agglomerations located in this zone and to the nature of the soils.

\section{REFERENCES}

Association Française de Normalisation (AFNOR). 1997. Recueil des Normes françaises Environnement. Tomes 1, 2, 3 et 4, 1372

Aouatif Fahssi., Hameed Saleh Ali Yahya., Rachid Touzani., Abdelhafid Chafi1. 2016. Evaluation spatiotemporelle de la contamination métallique des ressources hydriques superficielles de la basse Moulouya. J. Mater. Environ. Sci. 7 (7) (2016) 2404-2423. BELGHYTI D. 2004. Etude de cadrage de la biodiversite du bassin versant de la Moulouya et recensement des activites polluantes. ENDA Maghreb, 44.

BOUABDLA. I, SAIDI N., M'RABET S., Escarre et Leblanc M., 2005. Oued Moulouya : vecteur de transport des metaux lourds (Maroc). Rev. Sci. Eau, 18, 199-213.

Buggy C.J., Tobin J. M., 2008. Environ. Seasonal and spatial distribution of metals in surface sediment of an urban estuary. Pollut, 155, 308-319.

COMBE M. et SIMONOT M. 1971b. La Moyenne Moulouya". Notes et Memoires. Service Geologique. Maroc 231.

COMBE M. et SIMONOT M., 1971a. La Haute Moulouya, le sillon d'Itzer- Enjil et le massif de Bou-Mia- Aouli. Notes et Memoires. Service Geologique. Maroc, 231, 193-201.

Cook, J. A., Andrew, S. M and Johnson, M. S (1990) Lead, zinc, cadmium and fluoride in small mammals from contaminated grassland established on fluorspar tailings. Water, Air, and Soil Pollution, 51: 43-54. DOI: 10.1007/BF00211502.

Danielle L., Agnès L., Sandrine J., Jérôme M., Alain B. 2008. Guide pratique des substances toxiques. 30-74.

DAVIES B. D. et BALLINGER R. C., 1990. Heavy metals in soils In north Somerset, England, With special reference to contamination from base metal mining in the Mendips. Environ. Geochem. Health, 12, 291-300.

Deniseger J., Erickson J., Austin A., Roch M., Clark M.J.R. The effects of decreasing heavy metal concentrations on the biota of Buttle Lake, Vancouver Island, British Columbia. Water Res. 24 (1990) 403-416.
Derwich E., Benaabidate L., Zian A., Sadki O., Belghity D. 2010. Caractérisation physico-chimique des eaux de la nappe alluviale du haut Sebou en aval de sa confluence avec Oued Fes. Larhyss Journal, 08, 101-112.

Devallois V., 2009. Transferts et mobilité des éléments traces métalliques dans la colonne sédimentaire des hydrosystèmes continentaux. Thèse de doctorat, Université de ProvenceAcadémie d'Aix-Marseille, 304p.

EL HACHIMI M. L., EL HANBALI M., FEKHAOUI M., BOUABDLI A., EL FOUNTI L. et SAIDI N. 2005. Impact d'un site minier abandonne sur l'environnement : cas de la mine de Zaida (haute Moulouya, Maroc). Bulletin de l'institut Scientifique, Rabat, section Sciences de la Terre, 27, 93-100.

EMBERGER A., 1965. Introduction a l'etude des mineralisations plombiferes de la haute Moulouya. Colloque sur les gites stratiformes. Notes et M. Serv. Geol. Maroc, 181, 167 174.

JUNG M. C., 2001. Heavy metal contamination of soils and waters in and around the Imcheon $\mathrm{Au}-\mathrm{Ag}$ mine, Korea. Appl. Geochem, 16, 1369-1375.

LIONS J. 2004. Etude hydrogeochimique de la mobilite de polluants inorganiques dans des sediments de curage mis en depot: experimentations, etudes in situ et modelisation. These de doctorat, Ecole Nationale Superieure des mines de Paris. France.

MAKHOUKH M., SBAA M., BERRAHOU A., ANCLOOSTER M. 2011. Contribution à l'étude de l'impact d'un site minier abandonné dans la haute Moulouya sur la qualité de l'Oued Moulouya, Maroc. Afrique SCIENCE. 07(3), $33-48$.

Norme Marocaine de qualité des eaux. Arrêté conjoint du Ministre de l'équipement et du Ministre chargé de l'aménagement du territoire, de l'urbanisme, de l'habitat et de l'environnement $\mathrm{n}^{\circ} 1275-01$ du 10 Chaabane 1423, (17- 102002) définissant la grille de qualité des eaux de surface. Rabat, Bulletin Officiel Maroc, $\mathrm{N}^{\circ} 5062$.

Rejsek F. 2002. Analyse des eaux, Aspects réglementaires et techniques. Série Sciences et technique de l'environnement, 360.

Rodier J. 2009. L'analyse de l'eau. 9éme édition, paris,

SERPAUD B., AL SHUKRY M., CASTEIGNEAU M. et MATEJKA G. 1994. Adsorption des metaux lourds $(\mathrm{Cu}, \mathrm{Zn}, \mathrm{Cd}$ et $\mathrm{Pb}$ ) par les sediments superficiels d'un cours d'eau: role du $\mathrm{pH}$, de la temperature et de la composition du sediment. Revues des sciences de l'eau, 7, 343-365.

Sin S.N., Chua H., Lo W., Ng L.M., 2001. Assessment of heavy metal cations in sediments of Shing Mun River, Hong Kong. Environ. Int, 26, 297-301.

Trefry JH., Presley BJ., 1976. Heavy metals in sediments from San Antonio Bay and the northwest Gulf of Mexico Enviro. Geol.. 1, 283-294

W.H.O / U.N.E.P.1995. Health risks from marine pollution in the Mediterranean. Implication for policy markers. EUR/HFATARGET 20, PART I, 255. 